\title{
PEMETAAN TANAH WAKAF DI KABUPATEN KARAWANG
}

\author{
Fakhruddin M \\ Puslitbang Bimas Agama dan Layanan Keagamaan \\ Badan Litbang dan Diklat Kementerian Agama RI \\ oedein@gmail.com
}

\begin{abstract}
This paper describes the policy implementation of benefaction (waqf) land certification in the District of Karawang, the Province of West Java. This study explains the fact that uncertified benefaction lands are higher in numbers compared to the certified ones. Most of the benefaction lands are used for mosque and musalla. The administrative and coordinative process need to be increased in order to minimise data differences. The three matters have become the indicator and concluded that the society's understanding on the benefaction lands restricts in that they are merely for worship places used as mosque, musalla, and educational institution, as well as other useful needs for the society's interest. The awareness of endowment arises and maintained through the strong role of religious figures. Related to data of mapping of benefaction lands in Karawang, there are different data of the lands issued by three organisations. There are disputes of benefaction lands in Karawang that resulted from weak awareness of the importance of benefaction administration. The office of Religious Affairs of Karawang need to conduct more intensive cooperation with the local government of Karawang and the BPN (Badan Pertanahan Nasional/National Land Agency) in the intensification of land certification through the supervision and socialisation of benefaction. The low budget of benefaction within the Ministry of Religious Affairs of Karawang has contributed to the weak process of the certification of benefaction lands.
\end{abstract}

Keywords: Policy Implementation, Waqf Certification, Acte of Waqf.

\begin{abstract}
Abstrak
Artikel ini mendeskripsikan implementasi kebijakan sertifikasi tanah wakaf di Kabupaten Karawang Provinsi Jawa Barat. Kajian ini menjelaskan fakta bahwa, tanah wakaf yang belum bersertifikat masih jauh lebih besar jumlahnya dibandingkan yang sudah bersertifikat. Sebagian besar tanah wakaf dipergunakan untuk masjid dan mushalla. Proses- dan kinerja administratif dan kordinatif perlu ditingkatkan untuk meminimalisir terjadinya perbedaan data. Tiga hal tersebut menjadi indikator dan kemudian disimpulkan bahwa pemahaman masyarakat tentang tanah wakaf semata-mata untuk tempat ibadah yang penggunaannya diperuntukkan sebagai masjid, mushola, dan lembaga pendidikan dan keperluan lain yang bermanfaat untuk kepentingan umat. Kesadaran berwakaf masyarakat muncul dan terpelihara dikarenakan kuatnya peranan tokoh agama. Terkait dengan data pemetaan tanah wakaf di Karawang, terdapat perbedaan jumlah data tanah wakaf yang diterbitkan oleh tiga lembaga, Terdapat sengketa tanah wakaf di Karawang yang diakibatkan oleh lemahnya kesadaran masyarakat mengenai pentingnya administrasi perwakafan. Kantor Kementerian Agama Kabupaten Karawang perlu bekerjasama lebih intensif dengen Pemerintah Kabupaten Karawang dan BPN dalam percepatan sertifikasi tanah melalui pembinaan dan sosialisasi perwakafan. Minimnya anggaran untuk pos perwakafan di Kementerian Agama Kabupaten Karawang telah berkontribusi terhadap lemahnya proses sertifikasi tanah wakaf.
\end{abstract}

Kata kunci: Implementasi Kebijakan, Sertifikasi Wakaf, Akta Ikrar Wakaf. 


\section{PENDAHULUAN}

Sebagai masyarakat agraris, tanah merupakan bagian yang tidak terpisahkan dari kehidupan masyarakat Indonesia. Pemanfaatan tanah dipergunakan sebesar-besarnya untuk kepentingan rakyat demi tercapainya masyarakat yang adil dan makmur. Tanah menjadi salah satu faktor penting dalam pembangunan yang bersifat fisik, seperti gedung pemerintahan, sekolah, pabrik, dan lain-lain. Tanah juga sangat berperan untuk pembangunan masyarakat, baik dalam jumlah, kepemilikan, maupun proses peralihan haknya. Seiring waktu, tanah mengalami perubahan kedudukan dan fungsi melalui beberapa proses peralihan hak, seperti hibah, wakaf, dan jual beli. Salah satu proses peralihan hak yang pengaruhnya sangat besar pada kedudukan dan fungsi tanah adalah wakaf. Banyak sekali tempat-tempat ibadah, panti asuhan, sekolah/madrasah, pusat dakwah yang didirikan di atas tanah wakaf (Wibowo, 2006).

Hal tersebut menunjukkan betapa besar peranan wakaf bagi kepentingan umat Islam, baik dalam memfasilitasi kegiatan keagamaan dan sosial, maupun kegiatan-kegiatan akademik. Namun demikian, di Indonesia faktanya berbeda. Perwakafan saat ini menghadapi problem yang cukup rumit, karena pada awalnya permasalahan wakaf ini hanya ditangani oleh umat Islam secara perorangan, pemerintah tidak mengatur tata cara orang yang mewakafkan hartanya. Akibat tidak adanya pengaturan dari pemerintah tersebut, seringkali terjadi hal-hal yang merugikan bagi orang yang berwakaf, agama dan masyarakat, misalnya (a) Benda-benda wakaf tidak diketahui keadaannya; (b) Penjualan benda wakaf oleh ahli waris pewakaf; (c) Sengketa tanah/benda wakaf.

Kasus dan permasalahan di atas hanyalah contoh kecil dari sekian banyak kasus yang menimpa harta wakaf umat
Islam, yang tidak hanya berupa tanah masjid tetapi juga berupa tanah kuburan dan berbagai prasarana umat Islam lainnya. Kasus harta wakaf ternyata tidak hanya terjadi antara pihak umat Islam dengan pihak pemerintah, namun juga dengan keluarga pewakaf yang kemudian mengambil kembali wakaf tersebut dengan alasan tidak adanya bukti pewakafan tanah milik keluarganya itu. Melihat banyaknya dampak negatif ketika wakaf hanya menjadi hukum privat atau sebagai amal sukarela (voluntary), maka sejak jaman kolonial persoalan wakaf sebenarnya sudah diatur oleh pemerintah. Pasca kemerdekaan, soal wakaf juga diatur dalam UU Nomor 5 Tahun 1960 tentang Peraturan Dasar Pokok-Pokok Agraria (UUPA), kemudin ditindak lanjuti dengan PP Nomor 28 Tahun 1977 tentang Perwakafan Tanah Milik. Selanjutnya lahir Inpres Tahun 1999 yang mengantisipasi berlakunya Kompilasi Hukum Islam (KHI). Di era reformasi, untuk memaksimalkan potensi wakaf diterbikan UU No. 41 Tahun 2004 tentang Wakaf yang kemudian dilengkapi dengan turunannya yaitu PP No. 42 Tahun 2006 tentang Pelaksanaan UU No. 41 Tahun 2004 tentang Wakaf.

Terbitnya peraturan perundangundangan tentang wakaf tersebut secara perlahan dapat menjawab beberapa persoalanterkait wakaf. Namundemikian, harus diakui dalam implementasinya masih terdapat sejumlah kendala yang dihadapi masyarakat, salah satunya soal sertifikasi tanah wakaf. Hingga saat ini belum seluruh tanah wakaf bersertifikat. Berdasarkan data yang ada, pada 4 Januari 2017, jumlah data tanah wakaf saat ini di Indonesia adalah 4.359.443.170 m2. Luas tersebut berada pada 435.768 lokasi. Dari seluruhnya yang sudah bersertifikat adalah 287.608 lokasi $(65,90 \%)$ dan belum bersertifikat 148.160 lokasi $\quad(34,06 \%)$ (Sumber Laporan Direktur Pemberdayaan Wakaf). 
\begin{tabular}{lll}
\multicolumn{2}{c}{ Berdasarkan hasil kajian Tim } \\
Peneliti & Puslitbang & Kehidupan \\
Keagamaan & Badan Litbang dan Dikla
\end{tabular}

Kementerian Agama RI yang meneliti terkait sengketa tanah wakaf pada tahun 2014, diketahui bahwa terdapat sejumlah problem dalam sertifikasi tanah wakaf. Tidak dilakukannya sertifikasi tanah wakaf berdampak merugikan umat Islam, antara lain: (1) Jika dikemudian hari ada pihak-pihak yang menggugat kepemilikan tanah wakaf, nadzir bisa kehilangan tanah wakaf karena tidak memiliki legalitas formal; (2) Pada beberapa kasus, ahli waris dari wakif, tidak mengakui adanya perbuatan wakaf orang tuanya. Hal ini biasanya menjadi sengketa di pengadilan. Dalam beberapa kasus dimenangkan ahli waris; (3) Dinamika pembangunan dan perubahan sosial seringkali berefek pada perubahan tata ruang, sehingga terjadi ruislag atau tukar guling tanah wakaf. Dalam kasus tersebut, nadzir tidak memiliki posisi tawar yang kuat karena tidak adanya bukti sah atas tanah wakaf, (4) Terjadi perselisihan antara nadzir dengan wakif atau masyarakat terkait pemanfaatan tanah wakaf. Hal tersebut bisa dihindari jika ada dokumen sah wakaf yang biasanya mencantumkan penggunaan tanah wakaf (akad/shighat).

Untukmenjawabbeberapapersoalan tersebut, pemerintah sebenarnya telah menerbitkan PP Nomor 42 Tahun 20016 tentang Pelaksanaan UU No. 41 Tahun 2004 tentang Wakaf. Dalam pasal 31 disebutkan, dalam hal belum dibuatnya Akta Ikrar Wakaf (AIW) sementara wakif sudah meninggal, namun perbuatan wakaf sudah diketahui dua saksi maka dapat dibuatkan Akta Pengganti Akta Ikrar Wakaf (APAIW). Demikian halnya ketika AIW belum dibuatkan, sementara wakif dan dua saksinyapun sudah tidak ada (meninggal), maka pada Pasal 35 disebutkan bahwa kepala desa tempat benda wakaf tersebut berada wajib meminta pembuatan APAIW tersebut kepada PPAIW setempat.
Berdasarkan latar belakang di atas, penting dilakukan kajian terkait permasalahan sertifikasi tanah wakaf khususnya di daerah Karawang, Jawa Barat untuk melihat, berapa jumlah tanah wakaf, bagaimana kondisi tanah wakaf saat ini, berapa yang sudah bersertifikat dan berapa yang belum bersertifikat saat ini, apa saja kendala yang dihadapi masyarakat maupun pemerintah dalam hal sertifikasi tanah wakaf, serta sejauhmana tata cara sertifikasi tanah wakaf yang telah diatur dalam PP No. 42 Th 2006 tersebut. Melalui penelitian tentang sertifikasi tanah wakaf ini diharapkan dapat mendeskripsikan berbagai kendala yang ada dalam sertifikasi tanah wakaf secara lebih komprehensif, sehingga dapat dicarikan solusinya oleh pemerintah.

Selanjutnya, dalam penelitian ini dirumuskan permasalahan yang menjadi fokus riset ini, yaitu: 1). Mengapa sertifikasi tanah wakaf belum terlaksana (di lokasi penelitian)? Faktor apa yang menjadi penyebab sertifikasi wakaf tidak terlaksana (pemetaan persoalan)? 2). Bagaimana peran tokoh agama, pimpinan ormas keagamaan, dan pemerintah (Kepala Desa, KUA, BWI, Pemda, dan BPN) terkait adanya tanah wakaf yg belum bersertifikat di daerahnya? 3). Apa saja problem yang dihadapi Kankemenag dalam sertifikasi tanah wakaf? 4). Bagaimana penanganan tanah yang belum ber-AIW sementara wakif dan saksinya telah tiada? (sesuai Pasal 35 dari PP 42/2006).

Berdasarkan permasalahan penelitian di atas, maka tujuan penelitian ini antara lain: 1). Mengidentifikasi dan mendeskripsikan sertifikasi tanah wakaf yang belum terlaksana di lokasi penelitian, faktor apa yang menjadi penyebab (pemetaan persoalan); 2). Mendeskripsikan peran tokoh agama, pimpinan ormas keagamaan, dan pemerintah (Kepala Desa, KUA, BWI, 
Pemda, dan BPN) terkait adanya tanah wakaf yg belum bersertifikat di daerahnya; 3). Mendeskripsikan problem-problem yang dihadapi Kankemenag dalam sertifikasi wakaf? 4). Mendeskripsikan penanganan tanah wakaf yang wakif dan saksinya telah tiada sementara tanah tersebut belum ber-AIW (sesuai Pasal 35 dari PP 42/2006).

\section{METODE}

Kajianinimenggunakan pendekatan kualitatif. Pengambilan data dilakukan melalui tiga metode yaitu: wawancara, observasi, dan kajian dokumen. Penjelasan atas tiga metode tersebut sebagai berikut: Perrtama, wawancara. Jenis wawancara yang dilakukan adalah wawancara semi terstruktur. Tujuannya agar peneliti dapat lebih leluasa dan lebih terbuka dalam mengembangkan pertanyaan, sehingga suasana lebih hidup dan tidak monoton, namun tetap memiliki pijakan berdasarkan sistematika yang telah disusun, serta substansinya tetap fokus dan terarah. Wawancara dilakukan terhadap para tokoh agama dan masyarakat (Pengurus Yayasan/ Lembaga Keagamaan) yang terlibat dalam perwakafan tanah, pimpinan ormas keagamaan, pejabat daerah (KUA, BWI, Pemda, dan BPN). Sementara untuk data pendukung diperoleh dari review berbagai buku, hasil penelitian, dokumen dan laporan, baik dari institusi Kementerian Agama serta pemerintah daerah. Waktu penelitian adalah selama 15 hari, yaitu dari tanggal 21 Maret sampai 4 A pril 2014. Setelah pengumpulan data di lapangan, selanjutnya dilakukan analisis data. Analisis data dimulai dengan menelaah seluruh data yang tersedia. Pendekatan yang digunakan dalam analisis data adalah bersifat induktif yaitu melalui reduksi data, pengelompokkan, dan ketegorisasi data, dengan jalan abstraksi yang merupakan upaya memuat rangkuman inti, proses dan pernyataan.
Sebagai tahap akhir, sebelum kesimpulan dilakukan interpretasi yaitu mencoba untuk memaknai, mendiskusikan, membandingkan, mencocokkan, dengan teori yang ada.

Berdasarkan Sistem Informasi tentang Wakaf (SIWAK) Kementerian Agama, terdapat beberapa daerah yang merupakan provinsi tertinggi yang tanah wakafnya belum bersertifikat, yaitu Jawa Barat. Selanjutnya, dipilih salah satu kabupaten/kota yang tertinggi angka tanah wakaf yang belum bersertifikat, yaitu Kabupaten Karawang. Dari Kabupaten Karawang tersebut, kemudian selanjutnya ditetapkan 3 (tiga) Kecamatan yang tertinggi jumlah tanah wakaf yang belum bersertifikat sebagai lokus penelitian, yaitu Kecamatan Karawang Barat, Jatisari dan Cilamaya Kulon.

\section{LANDASAN KONSEPTUAL}

Para ulama berbeda-beda dalam mendefinisikan wakaf, sehingga implikasi fikih wakaf pun berbeda, seperti soal penukaran harta wakaf, wakaf dalam waktu tertentu, barang yang boleh diwakafkan dan pengelolaan wakaf. Secara etimologis, wakaf berasal dari perkataan Arab "Waqf" yang berarti "alHabs". Ia merupakan kata yang berbentuk masdar (infinitive noun) yang pada dasarnya berarti menahan, berhenti, atau diam. Apabila kata tersebut dihubungkan dengan harta, seperti tanah, binatang dan yang lain, ia berarti pembekuan hak milik untuk faedah tertentu (Ibnu Manzhur: 9/359).

Wakaf menurut Hanafiyah adalah menahan materi benda (al-'ain) milik Wakif dan menyedekahkan atau mewakafkan manfaatnya kepada siapapun yang diinginkan untuk tujuan kebajikan (Ibnu al-Humam: 6/203). Berdasarkan definisi ini, maka kepemilikan harta tetap di tangan wakif, bahkan wakif dapat menariknya sewaktu- 
waktu dan dapat pula menjualnya. Menurut Malikiyah, wakaf adalah menjadikan manfaat suatu harta yang dimiliki (walaupun pemilikannya dengan cara sewa) untuk diberikan kepada orang yang berhak dengan satu akad (shighat) dalam jangka waktu tertentu sesuai dengan keinginan Wakif (al-Dasuqi: 2/187). Definisi ini menegaskan bahwa harta wakaf tidak lepas dari kepemilikan wakif, namun wakaf tersebut mencegah wakif melakukan tidakan yang dapat melepaskan kepemilikannya dan wakif berkewajiban menyedekahkan manfaat serta tidak boleh menarik.

Menurut Syafi'iyah, wakaf adalah menahan harta yang bisa memberi manfaat serta kekal materi bendanya (al-'ain) dengan cara memutuskan hak pengelolaan yang dimiliki oleh Wakif untuk diserahkan kepada Nazhir yang dibolehkan oleh syariah (al-Syarbini: 2/376). Wakif sudah melepaskan hartanya untuk wakaf, sehingga tidak boleh melakukan apa saja terhadap harta wakaf, tidak boleh menjual, mewariskan dan tidak boleh dihibah serta tidak boleh menariknya kembali. Golongan ini mensyaratkan harta yang diwakafkan harus harta yang kekal materi bendanya (al-'ain), dalam artian harta yang tidak mudah rusak atau musnah, serta dapat diambil manfaatnya secara berterusan. Menurut Hanbaliah, wakaf adalah bahasa yang sederhana, yaitu menahan asal harta (tanah) dan menyedekahkan manfaat yang dihasilkan (Ibnu Qudamah: 6/185).

Menurut Majelis Ulama Indonesia (MUI), wakaf adalah menahan harta yang dapat dimanfaatkan tanpa lenyap bendanya, dengan cara tidak melakukan tindakan hukum terhadap benda tesebut, disalurkan pada sesuatu yang mubah (tidak haram) yang ada. Lalu, bagaimana menurut undang-undang di Indonesia? Dalam Undang-undang nomor 41 tahun 2004, wakaf diartikan: perbuatan hukum Wakif untuk memisahkan dan/ atau menyerahkan sebagian harta benda miliknya untuk dimanfaatkan selamanya atau untuk jangka waktu tertentu sesuai dengan kepentingannya guna keperluan ibadah dan/atau kesejahteraan umum menurut syariah.

Di kalangan fuqaha (ahli ilmu hukum Islam) sepakat bahwa praktik wakaf memerlukan unsur-unsur (rukun Unsur-unsur tersebut adalah: 1) pewakaf (waqif); 2) harta yang diwakafkan (mauquf bih); 3) penerima wakaf (mauquf 'alaih); 4) pernyataan atau ikrar wakaf (shighat); 5) pengelola (nadzir), baik berupa lembaga atau perorangan.

Wakaf sangat penting bagi pengembangan kehidupan keagamaan dan untuk kesejahteraan umat Islam. Namun, wakaf juga ibadah yang menyangkut hak dan kepentingan orang lain, sehingga diperlukan tertib administrasi dan aspek-aspek lain dalam kehidupan masyarakat agar hak dan kewajiban serta kepentingan masyarakat itu dapat berjalan dengan baik. Untuk mengatur masalah wakaf, pemerintah menerbitkan peraturan perundangundangan terkait wakaf. Dengan adanya peraturan perundang-undangan itu diharapkan ketertiban dalam praktek perwakafan dapat terwujud hingga manfaatnyapun dapat dirasakan oleh masyarakat.

Campur tangan pemerintah dalam hal perwakafan mempunyai dasar yang kuat. Dalam Undang-Undang Dasar 1945 Pasal 29 ayat (1) di bawah bab Agama, dinyatakan bahwa Negara Republik Indonesia berdasarkan atas Ketuhanan Yang Maha Esa. Menurut Hazairin, norma dasar yang tersebut dalam Pasal 29 ayat (1) itu tafsirannya antara lain bermakna bahwa "Negara Republik Indonesia" wajib menjalankan syari'at Islam bagi orang Islam, syari'at Nasrani bagi orang Nasrani, syariat Hindu bagi orang Bali 
sekedar menjalankan syari'at (norma agama) itu memerlukan perantaraan Kekuasaan Negara. (Hazairin, 1983 : 34).

Kekuasaan Negara yang wajib menjalankan syari'at masing-masing agama yang diatur dalam Negara Republik Indonesia ini adalah kekuasaan negara yang berdasarkan UndangUndang Dasar Republik Indonesia. Hal ini disebabkan oleh syari'at yang berasal dari agama yang dianut warga Negara Republik Indonesia itu adalah kebutuhan hidup para pemeluknya. Di samping itu, pasal 29 ayat (2) UndangUndang Dasar 1945 dengan jelas juga menyebutkan bahwa negara menjamin kemerdekaan tiap-tiap penduduk untuk memeluk agamanya masing-masing untuk beribadat menurut agama dan kepercayaannya itu. Dilihat dari ayat (1) dan ayat (2) pasal 29 UUD 1945 tersebut jelas bahwa wakaf merupakan salah satu bentuk ibadat kepada Allah yang termasuk ibadah alamiah, yaitu ibadah berupa penyerahan harta (mal) yang dimiliki seseorang menurut cara-cara yang ditentukan.

Dalam Undang-Undang pokok Agraria No. 5/1960 telah dicantumkan adanya suatu ketentuan khusus mengenai masalah wakaf sebagaimana tersebut di dalam Pasal 49 yang memberikan ketentuan sebagai berikut: 1). Hak milik tanah badan-badan keagamaan dan sosial sepanjang dipergunakan untuk usaha dalam bidang keagamaan dan sosial diakui dan dilindungi. Badanbadan tersebut dijamin pula akan memperoleh tanah yang cukup untuk bangunan dan usahanya di bidang sosial dan keagamaan; dan 2). Untuk keperluan peribadatan dan keperluan suci lainnya, sebagaimana dimaksud dalam Pasal 14 dapat diberikan tanah yang dikuasai langsung oleh Negara dengan hak pakai.

Perwakafan tanah milik dilindungi dan diatur dengan Peraturan Pemerintah. Dari ketentuan pasal 49 ayat (3) HARMONI | Januari - Juni 2018 diatas jelas bahwa untuk melindungi berlangsungnya tanah perwakafan di Indonesia, Pemerintah akan memberikan pengaturan melalui Peraturan Pemerintah tentang perwakafan tanah milik. Peraturan Pemerintah itu baru dikeluarkan setelah 17 tahun berlakunya UU Pokok Agraria itu. Pada tanggal 17 Mei 1977 Pemerintah RI mengeluarkan Peraturan Pemerintah No. 28 tentang Perwakafan Tanah Milik diiringi dengan seperangkat Peraturan Pelaksanaannya oleh Departemen Agama dan Departemen Dalam Negeri dan Menteri Negara Agraria/Kepala Badan Pertanahan Nasional. Yang menjadi latar belakang dikeluarkannya Peraturan Pemerintah No. 28 tahun 1977 itu adalah: 1) Pada waktu yang lampau pengaturan tentang perwakafan tanah sebelum memenuhi kebutuhan juga tidak diatur secara tuntas dalam suatu Peraturan PerundangUndangan, sehingga memudahkan terjadinya penyimpangan hakekat dan tujuan perwakafan itu sendiri; 2) Hal ini menimbulkan keresahan di kalangan umat Islam yang menjurus pada perasaan tidak percaya terhadap lembaga wakaf, padahal lembaga itu dapat dipergunakan sebagai salah satu sarana pengembangan kehidupan beragama, khususnya bagi umat Islam; dan 3) Dalam masyarakat banyak terjadi persengketaan mengenai wakaf tanah karena tidak jelasnya status tanah wakaf yang bersangkutan. (Muhammad Daud Ali, 1988 : 99).

Selanjutnya, pada tahun 1985 dimulai proyek kodifikasi hukum Islam melalui penyusunan draft Kompilasi Hukum Islam (KHI) yang dimulai sejak 1985 yang disusun oleh tim dari Kementerian Agama dan Mahkamah Agung. Draft tersebut kemudian disahkan melalui Intruksi Presiden (Inpres) pada tahun 1991. KHI merupakan rumusan fikih hasil ijtihad jama'i yang kemudian menjadi hukum positif yang mengikat bagi seluruh warga negara yang beragama Islam. Dalam KHI tersebut, terdapat 
bidang hukum perwakafan yang diatur dalam bab III.

Pada tanggal 27 Oktober 2004, Pemerintah mengeluarkan sebuah peraturan baru yaitu Undang-undang Nomor 41 Tahun 2004 tentang Wakaf. Undang-undang ini merupakan Undangundang pertama yang secara khusus mengatur wakaf. Dengan berlakunya Undang-undang ini, semua peraturan tentang perwakafan masih berlaku sepanjang tidak bertentangan dan/atau belum diganti dengan peraturan yang baru berdasarkan Undang-undang ini.

Secara umum banyak hal baru dan berbeda yang terdapat dalam UU No. 41/2004 bila dibandingkan dengan PP No. 28/1977 maupun KHI, walaupun banyak pula kesamaannya. Dapat dikatakan bahwa UU No. 41/2004 mengatur substansi yang lebih luas dan luwes bila dibandingkan dengan peraturan Perundang-undangan yang ada sebelumnya. Salah satu perbedaan UU No. 41/2004 dengan PP No. 28/1977 adalah ruang lingkup subtansi yang diaturnya. UU ini mengatur wakaf dalam lingkup yang lebih luas, tidak terbatas hanya pada wakaf tanah milik.

Undang-undang ini membagi benda wakaf menjadi benda tidak bergerak yaitu misalnya hak atas tanah, bangunan atau bagian bangunan, tanaman dan benda lain yang berkaitan dengan tanah serta hak milik atas rumah susun dan benda bergerak meliputi uang, logam mulia, surat berharga, kendaraan, hak atas kekayaan intelektual dan hak sewa. Khusus untuk benda bergerak berupa uang, UU No. 41/2004 mengaturnya dalam 4 pasal yaitu Pasal 28 sampai Pasal 31. Hal ini sejalan dengan fatwa Majelis Ulama Indonesia pada tahun 2002 yang isinya membolehkan wakaf uang. Hal berbeda berikutnya yang terdapat dalam UU No. 41/2004 adalah mengenai pengertian sekaligus rukun wakaf.
Namun, hal itu kemudian diubah oleh UU No 41/2004 pada Pasal 1 UU tersebut dinyatakan bahwa wakaf adalah perbuatan wakaf untuk memisahkan dan/ atau menyerahkan sebagian harta benda miliknya untuk dimanfaatkan selamanya atau jangka waktu tertentu dan sesuai dengan kepentingannya guna keperluan ibadah dan/atau kesejahteraan umum menurut syariat, jadi menurut ini wakaf sementara juga diperbolehkan asalkan sesuai dengan kepentingannya.

Selanjutnya, untuk implementasi dari UU No 41/2004 tersebut, pemerintah menerbitkan PP No 42 Tahun 2006 tentang Implementasi UU No 41 tahun 2004. PP tersebut ditindalanjuti dengan terbitnya Surat Edaran (SE) Menteri Agraria dan Tata Ruang/ Kepala Badan Pertanahan Nasional (BPN) No. 3062/ 020/ VII/ 2016 tentang Hal Petunjuk Pelaksanaan Pendaftaran Tanah Wakaf. Peraturanperaturan yang telah dikeluarkan oleh pemerintah Republik Indonesia, merupakan usaha pemerintah untuk menjaga dan melestarikan tanah wakaf yang ada di Indonesia.

\section{HASIL DAN PEMBAHASAN}

\section{Tanah Wakaf Kabupaten Karawang}

Secara administratif, Kabupaten Karawang terdiri atas 30 kecamatan, 297 desa dan 12 kelurahan. Dengan luas wilayah 1.753,27 $\mathrm{km} 2$ atau 3,73 persen dari luas Provinsi Jawa Barat, Karawang merupakan salah satu daerah yang memiliki lahan subur di Jawa Barat, sehingga sebagian besar lahannya digunakan untuk pertanian (Karawang dalam Angka Tahun 2016). Sedangkan secara demografis, berdasarkan data kependudukan tahun 2017, penduduk Kabupaten Karawang 2.189.599 jiwa. Adapun komposisi penduduk Kabupaten Karawang berdasarkan agama terdiri atas: Islam (2.147.840 jiwa) (98,09\%), Kristen (23.151 jiwa) (1,06\%), Katolik (10.479

\begin{tabular}{l|l} 
Jurnal Multikultural \& Multireligius Vol. 17 & No. 1
\end{tabular} 
jiwa) (0,48\%), Hindu (1.409 jiwa) (0,06\%), Buddha (6.451 jiwa) (0,29\%), Konghucu (269 jiwa) (0,01\%) (Data Kementerian Agama Kabupaten Karawang Tahun 2017).

Dari data kependudukan di atas, terlihatjelasbahwamasyarakatKabupaten Karawang dihuni oleh mayoritas muslim dan praktik keagamaan Islam begitu kental dalam kehidupan masyarakat muslim Karawang. Salah satu praktik keagamaan Islam yang begitu kuat dalam masyarakat di Karawang adalah praktik wakaf yang telah diatur dalam figh muamalah dan peraturan perundangundangan di Indonesia (Wawancara KH. Encep, 28 Maret 2017).

Mengakarnya praktik wakaf dalam masyarakat muslim di Kabupaten Karawang tidak dapat dilepaskan dari keyakinan kuat mereka untuk menjalankan perintah Allah. Di samping itu, praktik wakaf ini diyakini dapat membantu masyarakat khususnya masyarakat muslim di Karawang di antaranya wakaf tanah darat yang dipergunakan untuk lahan pembangunan masjid, pesantren, madrasah dan majlis ta 'lim. (KH. Ade Fatahillah, Rois Syuriah. Wawancara. 28 Maret 2017). Selain wakaf tanah darat, di Karawang juga telah berlangsung sejak lama praktik mewakafkan tanah sawah yang hasil panennya akan dimanfaatkan untuk membiayai aktifitas pemeliharaan masjid dan kebutuhan lain yang terkait dengan aktifitas masjid dan aktifitas keagamaan Islam di Karawang. (KH Abdul Fatah, Nadzir. Wawancara. 29 Maret 2017). Kedua pandangan tersebut senada dengan penjelasan yang menyebutkan bahwa wakaf yang disyariatkan Islam mempunyai 2 (dua) dimensi sekaligus. Pertama, dimensi religius, di mana wakaf merupakan anjuran agama Allah yang perlu dipraktikkan pada masyarakat muslim, sehingga mereka yang memberi wakaf (waqif) mendapat pahala dari Allah karena melakukan anjuran tersebut. Kedua, dimensi sosial ekonomi, di mana kegiatan wakaf melalui uluran tangan sang dermawan telah membantu sesama untuk saling tenggang rasa, sehingga dapat menimbulkan rasa cinta kasih kepada sesama manusia (Departemen Agama RI, 2003: 48).

Keyakinan ini menjadi faktor penting yang menyebabkan besarnya praktik perwakafan di Kabupaten Karawang yang tercatat memiliki tanah wakaf sebanyak 5.636 lokasi, dengan luas 7.768.315 m2. Namun demikian, dari sekian banyak jumlah tanah wakaf tersebut status tanah wakafnya beragam, yakni sebagai berikut: 1). 2.503 (44,41\%) tanah wakaf sudah didaftarkan ke Badan Pertanahan Nasional Kabupaten Karawang; 2). 221 (3,92\%) tanah wakaf sedang dalam proses penerbitan sertifikat; dan 3). 2.912 (51,67\%) tanah wakaf belum bersertifikat. (Ubaidillah, Penyelenggara Syariah Kantor Kementerian Agama Kabupaten Karawang. Wawancara. 23 Maret 2017).

Selanjutnya, dalam hal penggunaannya, dari 5.636 lokasi tanah wakaf tersebut digunakan untuk masjid sebanyak 2.158 lokasi (38,29\%), langgar/mushalla 1.392 lokasi $(24,70 \%)$, sekolah/madrasah 721 lokasi (12,79\%), kuburan/makam sebanyak 149 lokasi $(2,64 \%)$, majelis taklim/pondok pesantren dan lembaga sosial lainnya sebanyak 1.216 lokasi (21,58\%). Tanah wakaf terluas di Kabupaten Karawang terdapat di Kecamatan Cilamaya Kulon dan Kecamatan Ciampel merupakan wilayah yang memiliki tanah wakaf paling sedikit di Kabupaten Karawang. (Ubaidillah, Penyelenggara Syariah Kantor Kementerian Agama Kabupaten Karawang. Wawancara. 23 Maret 2017).

Kondisi serupa terjadi pula di tiga kecamatan yang menjadi lokasi penelitian 
pemetaan tanah wakaf di Kabupaten Karawang, yakni di Kecamatan Karawang Barat, Kecamatan Jatisari dan Kecamatan Cilamaya Kulon, dengan mengacu pada tiga data yang terdapat di Penyelenggara Syariah Kantor Kementerian Agama Kabupaten Karawang, KUA dan Data SIWAK Direktorat Wakaf Kementerian Agama Republik Indonesia.

\section{Data Penyelenggara Syariah Kantor Kementerian Agama Kabupaten Karawang}

\section{Kecamatan Karawang Barat}

Kecamatan Karawang Barat tercatat memiliki tanah wakaf sebanyak 334 lokasi seluas 151,670 $\mathrm{m}^{2}$ dengan status tanah wakaf sebagai berikut: 1). 91 tanah wakaf dengan luas tanah $64.434 \mathrm{~m}^{2}(26,97 \%)$ sudah bersertifikat; 2). 21 tanah wakaf dengan luas tanah $3.654 \mathrm{~m} 2 \quad(1,53 \%)$ sudah didaftarkan di BPN Karawang; 3). 222 tanah wakaf dengan luas tanah $83.582 \mathrm{~m}^{2}$ (34,99\%) belum didaftarkan di BPN Karawang; dan 4). 243 tanah wakaf dengan luas $87.236 \mathrm{~m}^{2}(36,51 \%)$ belum bersertifikat. Dalam hal penggunaannya, dari 334 lokasi tanah wakaf tersebut digunakan untuk masjid sebanyak 109 lokasi dengan luas $46.367 \mathrm{~m}^{2}(30,57 \%)$, langgar/mushalla 87 lokasi dengan luas $10.005 \mathrm{~m}^{2}(6,60 \%)$, sekolah/madrasah 61 lokasi dengan luas $19.416 \mathrm{~m}^{2}(12,80 \%)$, kuburan/makam sebanyak 18 lokasi dengan luas $45.486 \mathrm{~m}^{2}(29,99 \%)$, majelis taklim/pondok pesantren dan lembaga sosial lainnya sebanyak 59 lokasi dengan luas $30.397 \mathrm{~m}^{2}(20,04 \%)$.

\section{Kecamatan Jatisari}

Kecamatan Jatisari tercatat memiliki tanah wakaf sebanyak 269 lokasi seluas $722.894 \mathrm{~m}^{2}$ dengan status tanah wakaf sebagai berikut: 1). 109 tanah wakaf dengan luas tanah $258.460 \mathrm{~m}^{2}(21,77 \%)$ sudah bersertifikat; 2). 4 tanah wakaf dengan luas tanah $473 \mathrm{~m}^{2}(0,04 \%)$ sudah didaftarkan di BPN Karawang; 3).156 tanah wakaf dengan luas tanah 463.961 $\mathrm{m}^{2}(39,08 \%)$ belum didaftarkan di BPN Karawang; dan 4). 160 tanah wakaf dengan luas $464.434 \mathrm{~m}^{2}$ (39,121\%) belum bersertifikat. Dalam hal penggunaannya, dari 269 lokasi tanah wakaf tersebut digunakan untuk masjid sebanyak 138 lokasi dengan luas $418.790 \mathrm{~m}^{2}$ (57,93\%), langgar/mushalla 30 lokasi dengan luas $20.119 \mathrm{~m}^{2}$ (2,78\%), sekolah/madrasah 34 lokasi dengan luas $56.290 \mathrm{~m}^{2}(7,79 \%)$, kuburan/makam sebanyak 9 lokasi dengan luas $12.963 \mathrm{~m}^{2}(1,79 \%)$, majelis taklim/pondok pesantren dan lembaga sosial lainnya sebanyak 58 lokasi dengan luas $214.732 \mathrm{~m}^{2}(29,70 \%)$.

\section{Kecamatan Cilamaya Kulon}

Kecamatan Cilamaya Kulon tercatat memiliki tanah wakaf sebanyak 422 lokasi seluas $1.123 .009 \mathrm{~m}^{2}$, dengan status tanah wakaf sebagai berikut: 1). 150 tanah wakaf dengan luas tanah $380.236 \mathrm{~m}^{2}$ (20,38.\%) sudah bersertifikat; 2). 0 tanah wakaf dengan luas tanah 0 $\mathrm{m}^{2}(0,00 \%)$ sudah didaftarkan di BPN Karawang; 3).272 tanah wakaf dengan luas tanah $742.774 \mathrm{~m}^{2}(39,81 \%)$ belum didaftarkan di BPN Karawang; dan 4). 272 tanah wakaf dengan luas $742.774 \mathrm{~m}^{2}$ $(39,81 \%)$ belum bersertifikat. Dalam hal penggunaannya, dari 422 lokasi tanah wakaf tersebut digunakan untuk masjid sebanyak 182 lokasi dengan luas 613.584 $\mathrm{m}^{2}(55,53 \%)$, langgar/mushalla 89 lokasi dengan luas $135.158 \mathrm{~m}^{2}(12,23 \%)$, sekolah/ madrasah 56 lokasi dengan luas 150.595 $\mathrm{m}^{2}(13,63 \%)$, kuburan/makam sebanyak 7 lokasi dengan luas $11.505 \mathrm{~m}^{2}(1,04 \%)$, majelis taklim/pondok pesantren dan lembaga sosial lainnya sebanyak 88 lokasi dengan luas $194.166 \mathrm{~m}^{2}$ (17,57\%). 


\section{Data Kantor Urusan Agama (KUA) di Tiga Kecamatan}

\section{Kecamatan Karawang Barat}

Berdasarkan data yang tercatat di Kantor Urusan Agama (KUA) Kecamatan Karawang Barat tercatat memiliki tanah wakaf sebanyak 352 lokasi seluas 187.981 $\mathrm{m}^{2}$, dengan status tanah wakaf sebagai berikut: 1). 91 tanah wakaf dengan luas tanah $64.434 \mathrm{~m}^{2}$ sudah bersertifikat; 2). 24 tanah wakaf dengan luas tanah 3.654 sudah didaftarkan di BPN Karawang; 3). 237 tanah wakaf dengan luas tanah 119.902 $\mathrm{m}^{2}$ belum didaftarkan di BPN Karawang; dan 4). 261 tanah wakaf dengan luas $123.547 \mathrm{~m}^{2}$ belum bersertifikat. Dalam hal penggunaannya, dari 352 lokasi tanah wakaf tersebut digunakan untuk masjid sebanyak 128 lokasi, langgar/mushalla 95 lokasi, sekolah/madrasah 41 lokasi, kuburan/ makam sebanyak 22 lokasi, majelis taklim/pondok pesantren dan lembaga sosial lainnya sebanyak 66 lokasi.

Tanah wakaf terluas di Kecamatan Karawang Barat terdapat di Kelurahan Karangpawitan, yakni seluas $40.264 \mathrm{~m}^{2}$ dan luas tanah wakaf terkecil terdapat di Kelurahan Adiarsa Barat, yakni seluas $6.013 \mathrm{~m}^{2}$.

\section{Kecamatan Jatisari}

Data Kantor Urusan Agama (KUA) Kecamatan Jatisari tercatat memiliki tanah wakaf sebanyak 291 lokasi seluas 634.684 $\mathrm{m}^{2}$ dengan status tanah wakaf sebagai berikut: 1). 114 tanah wakaf dengan luas tanah $263.358 \mathrm{~m}^{2}$ sudah bersertifikat; 2). 1 tanah wakaf dengan luas tanah $1.927 \mathrm{~m}^{2}$ sudah didaftarkan di BPN Karawang; 3). 176 tanah wakaf dengan luas tanah 364.060 $\mathrm{m}^{2}$ belum didaftarkan di BPN Karawang; dan 4). 177 tanah wakaf dengan luas $371.326 \mathrm{~m}^{2}$ belum bersertifikat. Dalam hal penggunaannya, dari 291 lokasi tanah wakaf tersebut digunakan untuk masjid sebanyak 131 lokasi, langgar/ mushalla 36 lokasi, sekolah/madrasah 38 lokasi, kuburan/makam sebanyak 9 lokasi, majelis taklim/pondok pesantren dan lembaga sosial lainnya sebanyak 83 lokasi.

Tanah wakaf terluas di Kecamatan Jatisari terdapat di Desa Jatiragas, yakni seluas $71.009 \mathrm{~m}^{2}$ dan luas tanah wakaf terkecil terdapat di Desa Situdam, yakni seluas $1.701 \mathrm{~m}^{2}$.

\section{Kecamatan Cilamaya Kulon}

Kantor Urusan Agama (KUA) Kecamatan Cilamaya Kulon tercatat memiliki tanah wakaf sebanyak 456 lokasi dengan luas $1.155 .558 \mathrm{~m}^{2}$, dengan status tanah wakaf sebagai berikut: 1). 149 tanah wakaf dengan luas tanah 365.609 $\mathrm{m}^{2}$ sudah bersertifikat; 2 ). 28 tanah wakaf dengan luas tanah $55.362 \mathrm{~m}^{2}$ sudah didaftarkan di BPN Karawang; 3). 251 tanah wakaf dengan luas tanah 679.256 $\mathrm{m}^{2}$ belum didaftarkan di BPN Karawang; dan 4). 279 tanah wakaf dengan luas $734.617 \mathrm{~m}^{2}$ belum bersertifikat. Dalam hal penggunaannya, dari 456 lokasi tanah wakaf tersebut digunakan untuk masjid sebanyak 193 lokasi, langgar/ mushalla 97 lokasi, sekolah/madrasah 50 lokasi, kuburan/makam sebanyak 9 lokasi, majelis taklim/pondok pesantren dan lembaga sosial lainnya sebanyak 107 lokasi.

Tanah wakaf terluas di Kecamatan Cilamaya Kulon terdapat di Desa Pasirjaya, yakni seluas 106,769 $\mathrm{m}^{2}$ dan luas tanah wakaf terkecil terdapat di Desa Tegalurung, yakni seluas 11,979 $\mathrm{m}^{2}$.

\section{Data SIWAK Direktorat Wakaf Kementerian Agama RI}

\section{Kecamatan Karawang Barat}

Kecamatan Karawang Barat tercatat memiliki tanah wakaf sebanyak 328 
lokasi, dengan status tanah wakaf sebagai berikut: 1). 103 tanah wakaf sudah bersertifikat; 2). 225 tanah wakaf belum bersertifikat. Dalam hal penggunaannya, dari 328 lokasi tanah wakaf tersebut digunakan untuk masjid sebanyak 112 lokasi, langgar/mushalla 83 lokasi, sekolah/madrasah 30 lokasi, kuburan/ makam sebanyak 22 lokasi, majelis taklim/pondok pesantren dan lembaga sosial lainnya sebanyak 81 lokasi.

\section{Kecamatan Jatisari}

Kecamatan Jatisari tercatat memiliki tanah wakaf sebanyak 277 lokasi, dengan status tanah wakaf sebagai berikut: 1). 32 tanah wakaf sudah bersertifikat; 2). 245 tanah wakaf belum bersertifikat. Dalam hal penggunaannya, dari 277 lokasi tanah wakaf tersebut digunakan untuk masjid sebanyak 140 lokasi, langgar/ mushalla 20 lokasi, sekolah/ madrasah 37 lokasi, kuburan/makam sebanyak 8 lokasi, majelis taklim/ pondok pesantren dan lembaga sosial lainnya sebanyak 72 lokasi.

\section{Kecamatan Cilamaya Kulon}

Kecamatan Cilamaya Kulon tercatat memiliki tanah wakaf sebanyak 424 lokasi, dengan status tanah wakaf sebagai berikut: 1). 291 tanah wakaf sudah bersertifikat; 2). 738 tanah wakaf belum bersertifikat. Dalam hal penggunaannya, dari 424 lokasi tanah wakaf tersebut digunakan untuk masjid sebanyak 184 lokasi, langgar/mushalla 94 lokasi, sekolah/madrasah 44 lokasi, kuburan/ makam sebanyak 7 lokasi, majelis taklim/ pondok pesantren dan lembaga sosial lainnya sebanyak 75 lokasi.

Demikian data pemetaan tanah wakaf di Kabupaten Karawang, khususnya di tiga kecamatan yakni Kecamatan Karawang Barat, Kecamatan
Jatisari dan Kecamatan Cilamaya Kulon, yang diperoleh dari tiga lembaga yang berada di lingkungan Kementerian Agama Republik Indonesia. Dari data tersebut, terdapat beberapa hal yang menarik untuk dianalisis seputar data yang dikeluarkan dari ketiga lembaga otoritatif tersebut, yakni sebagai berikut: 1) Dari ketiga data di atas, terlihat jelas bahwa jumlah status tanah wakaf yang belum bersertifikat masih jauh lebih besar jumlahnya dibandingkan yang sudah bersertifikat; 2) Peruntukan/penggunaan tanah wakaf di tiga kecamatan tersebut sebagian besar dipergunakan untuk masjid dan mushalla. Sedangkan untuk lembaga pendidikan, seperti sekolah/ madrasah dan pesantren, masih jauh lebih rendah dibandingkan peruntukan rumah ibadah; 3) Dari data yang dikeluarkan oleh ketiga lembaga tersebut, terdapat perbedaan data yang cukup signifikan perihal perbedaan jumlah status tanah wakaf dan penggunaan/ peruntukan tanah wakafnya; dan 4) Perbedaan data dari ketiga lembaga tersebut sesungguhnya memperlihatkan bahwa ada proses-proses dan kinerja administratif dan koordinatif yang perlu ditingkatkan untuk meminimalisir terjadinya perbedaan data tersebut.

Data mengenai jumlah tanah wakaf, status dan penggunaannya, sebagaimana disebut di atas, merupakan potret nyata di Kabupaten Karawang. Data tersebut memperlihatkan dengan jelas bahwa besarnya jumlah tanah wakaf di Karawang belum berbanding lurus dengan besarnya jumlah status tanah wakaf yang sudah bersertifikat. Masih banyaknya tanah wakaf yang belum memiliki kepastian hukum, baik data fisik maupun kepastian data secara yuridis, telah menjadi pemicu munculnya konflik tanah wakaf di masyarakat akibat tidak didaftarkannya tanah wakaf melalui prosedur perwakafan secara hukum. Kondisi semacam inilah yang kemudian menyebabkan ahli waris pewakaf 
(waqif) seringkali mempersoalkan tanda bukti, baik secara otentik maupun di bawah tangan, bahwa orang tua (pewaris atau waqif) benar-benar telah mewakafkan hak atas tanahnya kepada pengelola dan penerima wakaf (nadzir). Padahal, berbagai peraturan sudah jelas memberikan persyaratan dan pengaturan tentang prosedur perwakafan, sampai dilakukannya pendaftaran tanah wakaf di Kantor Pertanahan Kabupaten/Kota dengan mendasarkan pada ketentuan Undang-Undang No. 41 Tahun 2004 tentang Wakaf dan Peraturan Pemerintah No. 24 Tahun 1997 tentang Pendaftaran Tanah. Namun, pada kenyataannya di masyarakat, peraturan tersebut tidak dilaksanakan dengan benar dan baik, sehingga menyebabkan tidak adanya jaminan kepastian hukum atas perbuatan hukum Waqif yang telah melakukan perwakafan tanah hak miliknya.

Situasi semacam ini terjadi di Kabupaten Karawang, seperti terlihat pada kasus sengketa lahan masjid wakaf antara pengurus/takmir atau jemaah masjid dengan ahli waris lahan, sebagaimana dilansir beberapa media lokal dan nasional yang memang semakin marak terjadi di Kabupaten Karawang, Jawa Barat. Masalah itu terjadi karena ada pihak ahli waris yang tidak menerima kalau lahan yang mereka miliki sebelumnya telah diwakafkan oleh orangtuanya. Peristiwa ini bahkan mendapat perhatian serius dari kepala daerah di Karawang yang menyarankan agar pengelola masjid yang berasal dari pemberian masyarakat atau wakaf segera melakukan sertifikasi tanah masjid. Hal itu penting supaya tidak ada lagi sengketa antara pengurus masjid dengan ahli waris. (https://www. merdeka.com/peristiwa/ sengketa-masjid-wakaf-dengan-ahliwaris-marak-terjadi-di-karawang.html, diakses 2 April 2017).

Beberapa peristiwa serupa dengan kasus berbeda juga terjadi di Karawang yakni konflik ahli waris dan nadzir di lembaga Persatuan Islam (PERSIS) Kabupaten Karawang. Konflik ini bahkan sudah ditangani oleh pihak kepolisian dan sudah masuk ke acara persidangan di pengadilan Kabupaten Karawang. (Jajang, Penghulu KUA Karawang Barat. 28 Maret 2017). Selain itu, ada juga sengketa tanah wakaf di Karawang antara Pihak Pesantren Tahsinul Akhlak di Desa Sukakerta Kecamatan Cilamaya Kulon, Kabupaten Karawang dengan pihak penggugat. Sengketa yang dimenangkan oleh pihak pesantren ini juga telah ditangani oleh Polres Karawang dan telah ditangani oleh Pengadilan Negeri Karawang (http://www.radar-karawang. com/2014/02/persoalan-tanah-wakafpesantren.html, diakses 2 April 2017)

Untuk mengatasi terjadinya masalah-masalah serupa, Pemerintah Kabupaten Karawang pun mengeluarkan kebijakan membantu biaya penerbitan sertifikasi tanah masjid serta mengundang tokoh agama untuk menyosialisasikan program pensertifikatan lahan masjid (https://www.merdeka.com/peristiwa/ sengketa-masjid-wakaf-dengan-ahliwaris-marak-terjadi-di-karawang.html, diakses 2 April 2017)

Dalam persertifikasian tanah wakaf dari tahun 2014 sampai dengan tahun 2017, Pemerintah Daerah Kabupaten Karawang memang mempunyai program persertifikatan gratis. Pemerintah Daerah Karawang bekerjasama dengan Kementerian Agama untuk tahun anggaran 2014 telah mengajukan persertifikatan sebanyak 40 lokasi ke BPN dengan anggaran APBD Pemda Karawang. Namun, hingga pada tahun 2017 yang sudah selesai baru berjumlah 36 lokasi, dan 4 lokasi masih dalam proses di BPN Karawang. Selanjutnya, pada tahun 2015 dan 2016 disediakan slot sebanyak 70 lokasi (Staf Kesra Pemerintah Kabupaten Karawang. Wawancara. 28 Maret 2017) 
Selain Pemerintah Daerah Kabupaten Karawang, inisiatif serupa juga dilakukan oleh BPN Karawang dan Kementerian Agama Kabupaten Karawang untuk percepatan sertifikasi tanah wakaf yang dikukuhkan melalui Nota Kesepahaman tertanggal 31 Oktober 2016.

\section{Pemetaan Persoalan Sertifikasi Tanah Wakaf di Karawang}

\section{Substansi Hukum}

Fakta-fakta seputar sengketa tanah wakaf di Kabupaten Karawang sebagaimana dijelaskan di awal sesungguhnya memperlihatkan bahwa masyarakat belum sepenuhnya memberikan perhatian terhadap peraturan-peraturan dalam pelaksanaan wakaf, terutama bagi mereka yang melakukan atau memberikan wakaf. Padahal, dalam ketentuan syariah (Fiqh Wakaf menurut para ulama Mazhab Maliki, Hanafi, Syafii dan Hambali dan peraturan yang berlaku di Indonesia) telah diatur dengan jelas bahwa: 1 ). Wakaf adalah perbuatan hukum Wakif untuk memisahkan dan/atau menyerahkan sebagian harta benda miliknya, untuk dimanfaatkan selamanya atau untuk jangka waktu tertentu sesuai dengan kepentingannya, guna keperluan ibadah dan/atau kesejahteraan umum menurut Syariah; 2). Apabila wakif mewakafkan tanah miliknya, baik yang sudah maupun belum bersertifikat, maka hak milik atas tanah tersebut telah gugur; 3). Dalam hal Wakif mewakafkan tanah miliknya, maka perlu dilakukan Ikrar Wakaf sebagai pernyataan kehendak Wakif yang diucapkan secara lisan dan/atau tulisan kepada Nazhir untuk mewakafkan harta benda miliknya; 4). Dalam hal Ikrar Wakaf, maka pernyataan ikrar tersebut hendaknya dilanjutkan dengan tahap pembuatan Akta Ikrar Wakaf atau AIW sebagai bukti pernyataan kehendak
Wakif untuk mewakafkan harta benda miliknya guna dikelola Nazhir sesuai dengan peruntukan harta benda wakaf yang dituangkan dalam bentuk akta; 5). Nadzir yang disebut dalam Ikrar Wakaf dan Akta Ikrar Wakaf adalah pihak yang menerima harta benda wakaf dari Wakif untuk dikelola dan dikembangkan sesuai dengan peruntukannya.(PP Nomor 42 Tahun 2006 tentang Pelaksanaan UU Nomor 41 Tahun 2004 tentang Wakaf, Pasal 1; Untrisna, 2006: 27-30; Direktorat Jenderal Bimas Islam, 2006: 1-4).

Dengan demikian, secara yuridis, masalah perwakafan tanah milik yang diatur dalam fiqh wakaf dan peraturan pemerintah tersebut bermakna tegas bahwa agama dan negara memberikan perlindungan terhadap perwakafan tanah milik yang peruntukan dan penggunaannya sangat bermanfaat bagi kepentingan umat. Namun, pada kenyataannya, ketentuan-ketentuan ini belum sepenuhnya dipahami secara utuh oleh masyarakat seiring dengan masih adanya peristiwa sengketa tanah wakaf di masyarakat khususnya yang terjadi di Kabupaten Karawang (Kasubag TU Kementerian Agama Kabupaten Karawang. Wawancara. 29 Maret 2017). Di samping itu, terjadi pula kesalahan penggunaan wakaf dari aspek subtansi hukum maupun tujuan dari wakaf itu sendiri, seperti terjadinya peristiwa tukar guling tanah wakaf menjadi lahan perumahan milik perusahaan pengembang serta penguasaan tanah wakaf oleh nazhir secara turun-temurun (H. Saeful Bahri, Kepala KUA Karawang Timur. Wawancara. 29 Maret 2017).

Kasus lainnya adalah penggunaan lahan tanah wakaf menjadi bangunan rumah toko dan pembangunan tower oleh pihak ahli waris. (Zaenal, PenyuluhAgama Islam KUA Karawang Timur. Wawancara. 29 Maret 2017). Sesungguhnya dua kasus terakhir ini, jika ditinjau dari aspek yuridis tentu akan berdampak hukum, 
sebab telah diatur secara tegas bahwa apabila setiap orang yang dengan sengaja mengubah peruntukan harta benda wakaf tanpa izin dipidana penjara paling lama 4 (empat) tahun dan/atau pidana denda paling banyak Rp 400.000.000,00 dan setiap orang yang dengan sengaja menggunakan atau mengambil fasilitas atas hasil pengelolaan dan pengembangan harta benda wakaf melebihi jumlah yang ditentukan dipidana dengan pidana penjara paling lama 3 (tiga) tahun dan/ atau pidana denda paling banyak $\mathrm{Rp}$. 300.000.000,00. (Lihat Pasal 40, Pasal 44 dan Pasal 67 PP Nomor 41 Tahun 2004).

Problem yang sering terjadi dalam pelaksanaan wakaf karena pada saat penyerahan harta wakaf oleh wakif kepada nazhir tanpa persetujuan dari calon ahli waris, sehingga begitu wakif meninggal, ada ahli warisnya yang meminta tanah orang tuanya dikembalikan atau menggugat melalui jalur hokum. Hal ini terjadi karena wakaf yang dilakukan tidak dengan cara yang benar, yaitu dicatatkan dengan dibuatkan Akta Ikrar Wakaf dihadapan PPAIW, selanjutnya didaftarkan di Kantor Pertanahan Kabupaten/Kota supaya dapat diterbitkan sertifikat Hak Wakaf yang mempunyai kepastian hukum. (Umi, Nuansa, Vol. 9 No. 1 Januari - Juni 2012).

\section{Struktur Hukum (Pelaksana Peraturan)}

Mengacu pada upaya sertifikasi tanah wakaf dan penanganan kasuskasus seputar tanah wakaf yang terjadi di masyarakat, maka untuk memperbaiki kondisi tersebut sesungguhnya tidak perlu perbaikan sistem melalui perubahan dan penyempurnaan peraturan baru yang akan dijadikan sebagai dasar penegakan hukum. Yang justeru perlu dilakukan adalah penegakan Peraturan Pemerintah tentang Wakaf yang sudah mengatur pasal pembinaan dan pengawasan, penyelesaian sengketa dan sanksi pidana dan administratif (Lihat PP Nomor 41 Tahun 2004 tentang Wakaf). Hal ini yang telah dilakukan oleh pihak kepolisian dan Pengadilan Agama Karawang, setelah sebelumnya melalui proses mediasi dan musyawarah dalam kasus sengketa tanah wakaf antara organisasi PERSIS Karawang dengan pihak ahli waris $(\mathrm{H}$. Engkos, Kepala KUA Karawang Barat dan Jajang, Penghulu KUA Karawang Barat. Wawancara. 22 Maret 2017)

Munculnya kasus-kasus di atas selain diperlukan upaya penegakan hukum, juga diperlukan percepatan sertifikasi tanah wakaf dan sosialiasi ketentuan hukum yang berlaku di Indonesia. Perlunya kerjasama antara Direktorat Wakaf Kementerian Agama RI melalui Kementerian Agama Kabupaten Karawang, Pemerintah Daerah Karawang, Badan Pertanahan Nasional di Karawang, tokoh agama dan masyarakat dalam hal penyelesaian hukum agama maupun hukum negara untuk penyelesaian permasalahan wakaf.

Salah satu upaya percepatan sertifikasi tanah wakaf tersebut dilakukan oleh Kementerian Agama Kabupaten Karawang dan BPN Karawang melalui Nota Kesepahaman tertanggal 31 Oktober 2016. Beberapa hal yang mengemuka dalam isi nota kesepahaman tersebut adalah penyebarluasan informasi melalui sosialisasi mengenai percepatan sertifikasi tanah wakaf, penyiapan dokumen yang diperlukan untuk sertifikasi tanah wakaf, pelaksanaan sertifikasi tanah wakaf dan pemantauan dan evaluasi kegiatan percepatan sertifikasi tanah wakaf (Dokumen Nota Kesepahaman Kementerian Agama Kabupaten Karawang dengan BPN Karawang Nomor 01 Tahun 2016 tentang Percepatan Sertifikasi Tanah Wakaf). Selain nota kesepahaman tersebut, BPN Karawang bahkan mendapatkan Surat 
Kementerian Agraria dan Tata Ruang/ Badan Pertanahan Nasional Nomor 3062/020/VII/2006, perihal Juklak Pelaksanaan Pendaftaran Tanah Wakaf. Dalam surat tersebut disebutkan bahwa BPN daerah harus melakukan percepatan legalisasi asset tanah wakaf di seluruh Indonesia.

\section{Budaya Hukum (Masyarakat/Wakif atau Nadzir)}

Sebagaimana telah disinggung di atas, permasalahan yang muncul seputar tanah wakaf di Kabupaten Karawang, selain disebabkan lemahnya pemahaman masyarakat terhadap substansi hukum dan belum maksimalnya struktur hukum dalam penanganan masalah perwakafan, juga disebabkan oleh budaya yang selama ini melekat dalam masyarakat Karawang. Budaya dimaksud adalah soal sikap dan mentalitas yang sesungguhnya sangat luhur dalam tradisi masyarakat Indonesia pada umumnya, yakni budaya mengasihi sesama, budaya memberi tanpa pamrih. Dua sikap dan mentalitas ini memang erat melekat dalam tradisi masyarakat Indonesia, sehingga ketika memberi tidak berpikir tentang urusan administratif yang disyaratkan dalam ketentuan perwakafan. Kenyataan ini merupakan fakta sosial yang telah berlangsung sejak lama (Kepala KUA Karawang Barat, Kepala KUA Jatisari dan Kepala KUA Cilamaya Kulon. Wawancara. 29 Maret 2017). Selain itu, nilai-nilai agama Islam tentang keikhlasan juga turut menjadi faktor penyebab banyaknya peristiwa akad wakaf tanpa proses pengadministrasian di lembaga-lembaga pemerintah yang berwenang mengurus tahapan sertifikasi tanah wakaf, baik di KUA, Kementerian Agama maupun di Kantor BPN Karawang (KH. Encep, Wakil Ketua PCNU Karawang. Wawancara. 23 Maret 2017).
Faktor lain yang turut berkontribusi bagi minimnya jumlah sertifikasi tanah wakaf di Kabupaten Karawang adalah adanya keengganan pihak wakif untuk melakukan pengurusan sertifikasi tanah wakaf oleh karena persoalan waktu untuk bersentuhan dengan hal ihwal birokrasi. Di samping itu, bagi tanah wakafnya yang sudah berstatus sertifikat, terkendala pula oleh keengganan wakif untuk melakukan pemisahan satu surat tanah menjadi dua atau lebih sertifikat guna memperjelas posisi tanah mana yang telah dan belum diwakafkan (Yadi Suparman, S.Ag, Kepala KUA Telaga Sari. Wawancara. 29 Maret 2017)

Meskipun kondisi ini merupakan potret umum di Kabupaten Karawang, namun dalam riset pemetaan tanah wakaf di Kabupaten Karawang ini, terdapat beberapa nadzir yang melakukan pengurusan dengan baik, bahkan menanggung pembiayaan pengurusan sertifikat tanah sebelum akhirnya diproses menjadi sertifikat tanah wakaf. Nadzir dimaksud di antaranya adalah KH Abdul Fatah yang mendapat amanah dari seorang wakif yang sangat dermawan di daerah Kecamatan Cilamaya Kulon (Abdul Rosyid), pemilik tanah persawahan yang luasnya berpuluh hektar di daerah Cilamaya (Munadi, Bendahara Nadzir Tanah Wakaf dari Abdul Rosyid. Wawancara. 29 Maret 2017)

Selanjutnya terkait dengan amanah pengelolaan tanah wakaf, kondisi ideal yang diharapkan dalam pengelolaan tanah wakaf juga terlihat dari kebersamaan dan transparansi keuangan yang diperoleh dari hasil produksi tanah wakaf berupa persawahan yang hasilnya digunakan untuk keperluan madrasah, masjid, honorarium guru madrasah dan keperluan lain yang terkait dengan keperluan umat Islam, seperti perayaan hari besar Islam. Kondisi ini terjadi dan dilakukan oleh KH Abdul Fatah, Munadi 
dan sejumlah pengurus lembaga Nadzir lainnya, yang memperoleh amanat dari Abdul Rosyid selaku Wakif. Pengumuman pelaporan penggunaan uang hasil produksi pertanian tersebut diumumkan di masjid saat sebelum berlangsungnya sholat Jumat dan momen lain ketika warga berkumpul bersama (KH. Abdul Fatah, Ketua Nadzir. Wawancara. 29 Maret 2017)

Gambaranmenarikmengenai model pengelolaan semacam ini sesunggunya disebabkan oleh sikap kejujuran dan ketulusan untuk mengemban amanah besar demi menjaga dan mengembangkan tanah wakaf yang manfaatnya begitu besar bagi kepentingan umat $(\mathrm{KH}$. Abdul Fatah, Abdul Zaka, H. Yusuf, Wakif di Cilamaya Kulon dan Karawang Barat. Wawancara. 29 Maret 2017)

Namun demikian, satu hal yang tetap menjadi harapan dan keinginan para nadzir dan wakif adalah adanya pembinaan dan penerangan dari pemerintah dan unsur terkait perwakafan lainnya, agar informasi seputar peraturan dan manajemen perwafakan dapat diketahui dan dipahami, baik oleh nadzir, wakif maupun oleh masyarakat (Maman, Ketua Muhammadiyah Karawang. Wawancara. 27 Maret 2017; Munadi, Bendahara Nadzir Tanah Wakaf dari Abdul Rosyid. Wawancara. 29 Maret 2017).

Peran Tokoh Agama, Pimpinan Ormas, dan Pemerintah (KUA, Kades, Kankemenag, BWI, BPN, Pemda, Baznas).

Mengenai peran tokoh agama, pimpinan ormas dan pemerintah, berdasarkan temuan lapangan dapat dikemukakan bahwa sesungguhnya peranan tokoh agama memang menjadi faktor penting bagi terbangun dan terbinanya kesadaran umat Islam untuk melakukan wakaf. Namun demikian, peranan tersebut perlu diperkuat materi dan substansinya mengenai pentingnya pengadministrasian tanah wakaf dengan baik dan benar, agar aset umat tersebut tetap terpelihara dan aman dari sengketa yang kemungkinan dapat terjadi di masa mendatang (H. Darif Priyatna, Kasi Bimas Islam Kantor Kementerian Agama Karawang, 29 Maret 2017). Pernyataan serupa juga disampaikan oleh para pejabat di lingkungan Kementerian Agama Kabupaten Karawang, KUA dan dua pimpinan ormas Islam, yakni NU dan Muhammadiyah Karawang.

Selain peranan tokoh agama, baik perseorangan maupun yang berafiliasi kepada ormas Islam, peran pemerintah khususnya KUA, Kantor Kementerian Agama Kabupaten Karawang, BPN, Pemda Karawang dan Kepala Desa, juga perlu ditingkatkan terutama dalam hal koordinasi, komunikasi dan penjajakan langsung tanah-tanah yang sudah berstatus tanah wakaf. Hal ini dikarenakan semua hulu dan hilir proses sertifikasi tanah wakaf sesungguhnya terjadi di lembaga-lembaga tersebut. Meskipun fakta di lapangan terkendala oleh problem minimnya SDM dan anggaran negara, namun yang cukup menggembirakan adalah adanya program Pemerintah Daerah Kabupaten Karawang untuk membiayai 70 sertifikasi tanah wakaf setiap tahun. Sangat baik lagi, adanya Program Nasional Kementerian Agraria yang diteruskan oleh BPN Karawang untuk mensertifikatkan tanah masyarakat di Karawang sebanyak 12.000 sertifikasi tanah. Meskipun program nasional tersebut tidak dikhususkan untuk program perwakafan, namun dapat membantu wakif dan nadzir yang melakukan pengurusan sertifikasi tanah wakaf. (Kasubag TU BPN Karawang. Wawancara. 23 Maret 2017) 


\section{Problem yang dihadapai Kantor Kementerian Agama Kabupaten Karawang dalam Sertifikasi Tanah Wakaf}

Mengenai problematika yang dihadapi oleh Kantor Kementerian Agama Kabupaten Karawang, terutama di Penyelenggara Syariah dan KUAKUA, adalah sebagai berikut: 1) Banyaknya tanah wakaf yang masih berstatus Girik atau kikitir, dan Akta Jual Beli; 2) Minimnya anggaran dalam DIPA Kantor Kementerian Agama Kabupaten Karawang untuk pengurusan sertifikasi tanah wakaf; 3) Tidak adanya SDM yang secara khusus menangani bidang perwakafan; dan 4) Minimnya pengarsipan dokumen perwakafan, termasuk belum maksimalnya alat-alat kantor untuk pengarsipan dokumen perwakafan.

Problem-problem tersebut memunculkan beberapa usulan, yakni: 1) Perlu peningkatan anggaran dalam DIPA Kantor Kementerian Agama Kabupaten Karawang baik untuk Penyelenggara Syariah maupun KUA dalam urusan perwakafan; 2) Perlu peningkatan pengadaan alat-alat pengarsipan dokumen perwakafan yang baik dan memadai; 3) Penganggaran dimaksud akan sangat bermanfaat bagi pembiayaan administrasi dan program pembinaan dan sosialisasi perwakafan ke masyarakat khususnya wakif dan nadzir; 4) Perlu pengadaan buku registrasi yang standar sesuai dengan buku registrasi yang dipergunakan untuk pendaftaran pernikahan di KUA. Hal ini dikarenakan dalam proses pencatatan pendaftaran masih menggunakan buku besar folio yang tidak dalam format khusus untuk kerapian administrasi dan registrasi; 5) Perlu penguatan sinergitas antar lembaga pemerintah dan antar pemerintah dengan tokoh agama dan masyarakat untuk percepatan program sertifikasi tanah wakaf di Karawang.
Dari potret tersebut terlihat bahwa di internal Kantor Kementerian Agama Kabupaten Karawang pun terdapat sejumlah kendala yang dihadapi dalam sertifikasi tanah wakaf. Hal ini memunculkan satu pemikiran bahwa dalam hal percepatan sertifikasi tanah wakaf sebaiknya pemerintah dapat menyelesaikan kendala-kendala tersebut melalui perbaikan sistem dan peningkatan anggaran.

\section{Penanganan Tanah yang Belum ber-AIW (Wakif dan Saksi Sudah Tiada)}

Berdasarkan temuan lapangan, peristiwa penanganan tanah yang belum ber-AIW, sementara wakif dan saksi sudah tiada, jarang sekali terjadi di Karawang. Meskipun di salah satu dari tiga kecamatan, yakni Kecamatan Karawang Timur, Kepala KUA selaku PPAIW pernah menerbitkan Akta Pengganti Akta Ikrar Wakaf, itupun jarang sekali sebagaimana jarangnya peristiwa demikian di Kabupaten Karawang. Dalam kondisi semacam ini, peranan Kepala Desa juga besar sekali keberadaannya, terutama bagi PPAIW yang berkewajiban untuk memeriksa/ meneliti segala persyaratan proses wakaf.

Dalam konteks ini, selain berkaitan dengan status tanah wakaf yang menjadi kendala dalam jaminan kepastian hukum tanah wakaf, kendala yang lain terletak pada ketidakpahaman pihakpihak tertentu dalam menjalankan prosedur wakaf dan sertifikasi tanah wakaf. Peranan PPAIW sangat penting dalam rangka penerbitan Sertifikat Tanah Wakaf, sehingga Tanah Wakaf tersebut mempunyai jaminan kepastian hukum. Dengan demikian, PPAIW bukan saja menyiapkan dokumen atau kelengkapan administrasi saja sebagai kelengkapan untuk mengajukan permohonan pendaftaran sertifikat tanah wakaf, tetapi juga sebagai pejabat yang dianggap 
mempunyai kompetensi dan kapabel untuk mewujudkan jaminan kepastian hukum.

\section{SIMPULAN}

Berdasarkan temuan dan pembahasan di atas dapat disimpulkan sebagai berikut: Pertama, masyarakat di Karawang, khususnya di Kecamatan Cilamaya Kulon, Jatisari dan Karawang Barat, masih memahami bahwa wakaf adalah semata-mata untuk tempat ibadah, yang penggunaannya diperuntukkan sebagai masjid, mushalla, dan lembaga pendidikan dan keperluan lain yang bermanfaat untuk kepentingan umat; Kedua, kesadaran berwakaf masyarakat muncul dan terpelihara dikarenakan kuatnya peranan tokoh agama dalam memberikan motivasi, penerangan dan pencerahan kepada masyarakat mengenai pentingnya berwakaf, meskipun penerangan tersebut belum disertai dengan penguatan pentingnya administrasi perwakafan;

Ketiga, terkait dengan data pemetaan tanah wakaf di Karawang, terdapat perbedaan jumlah data tanah wakaf yang diterbitkan oleh tiga lembaga, yakni Data Siwak Direktorat Wakaf Kementerian Agama RI, Penyelenggara Syariah Kantor Kementerian Agama Kabupaten Karawang dan Tiga KUA di Cilamaya Kulon, Jatisari dan Karawang Barat. Hal ini semestinya tidak terjadi apabila ada sinkronisasi kerja dan koordinasi maksimal antar ketiga lembaga tersebut;

Keempat, terdapat sengketa tanah wakaf di Karawang yang diakibatkan oleh lemahnya kesadaran masyarakat mengenai pentingnya administrasi perwakafan; Kelima, Kantor Kementerian Agama Kabupaten Karawang perlu bekerjasama lebih intensif dengen Pemerintah Kabupaten Karawang dan BPN dalam percepatan sertifikasi tanah melalui pembinaan dan sosialisasi perwakafan; Keenam, minimnya anggaran untuk pos perwakafan di Kementerian Agama Kabupaten Karawang memberikan efek terhadap lemahnya proses sertifikasi tanah wakaf.

\section{REKOMENDASI}

Berdasarkan kesimpulan di atas, penelitian pemetaan tanah wakaf di Kabupaten Karawang ini menghasilkan beberapa rekomendasi, yaitu: Pertama, Peranan tokoh agama dalam memberikan penerangan dan pencerahan kepada masyarakat mengenai pentingnya berwakaf harus disertai penguatan pada aspek pentingnya administrasi perwakafan. Dengan demikian, perlu kerjasama yang kuat antara Pemerintah (Pemda Karawang, BPN dan Kantor Kementerian Agama Karawang) dengan tokoh agama setempat; Kedua, terkait dengan data pemetaan tanah wakaf di Karawang, perlu sinkronisasi data yang valid dan aktual antara Direktorat Wakaf Kementerian Agama RI, Penyelenggara Syariah Kantor Kementerian Agama Kabupaten Karawang dan Tiga KUA di Kecamatan Cilamaya Kulon, Kecamatan Jatisari dan Kecamatan Karawang Barat;

Ketiga, perlu peningkatan anggaran dalam DIPA Kantor Kementerian Agama Kabupaten Karawang, baik untuk Penyelenggara Syariah maupun KUA dalam urusan perwakafan; Keempat, perlu peningkatan pengadaan alat-alat pengarsipan dokumen perwakafan yang baik dan memadai; Kelima, perlu pengadaan buku registrasi yang standar sesuai dengan buku registrasi yang dipergunakan untuk pendaftaran pernikahan di KUA. Hal ini dikarenakan dalam proses pencatatan pendaftaran masih menggunakan buku besar folio yang tidak dalam format khusus untuk kerapian administrasi dan registrasi. 


\section{UCAPAN TERIMA KASIH}

Di akhir tulisan ini, penulis sangat berterima kasih kepada Kepala Puslitbang Bimas Agama dan Layanan Keagamaan serta Kepala Badan Litbang dan Diklat Kementerian Agama RI yang telah memberikan kesempatan kepada penulis untuk melakukan penelitian tentang isu yang diangkat dalam tulisan ini, juga beberapa pihak dan informan yang terlibat dalam penggalian data dan informasi di dalamnya. Tidak ketinggalan, terima kasih juga penulis tujukan kepada Mitra Bestari dan Pengelola Jurnal Harmoni yang telah memberikan catatan dan saran untuk perbaikan tulisan ini, hingga bisa diterbitkan pada Jurnal Harmoni edisi kali ini.

\section{DAFTAR ACUAN}

Buku dan Artikel

Abbad, M. Zaid. Lembaga Perekonomian Ummat di Dunia Islam. Bandung: Angkasa. 2003. Abdul Halim. Hukum Perwakafan di Indoensia. Jakarta: Ciputat Press. 2005.

Anshori, Abdul Ghofuri. Hukum dan Praktik Perwakafan di Indonesia. Jakarta: Pilar Media. 2006.

B. Ripley, Randall. ,\& Franklin, Grace A. Bureucracy and Policy Implementation. Homewood: The Dorsey Press. 1982.

Departemen Agama RI. Pedoman Pengelolaan dan Pengembangan Wakaf. Jakarta: Direktorat Jendral Bimbingan Masyarakat Islam dan Penyelenggaraan Haji, 2003

Direktorat Pemberdayaan Wakaf Direktorat Jenderal Bimbingan Masyarakat Islam Kementerian Agama. Himpunan Peraturan Perundang-Undangan tentang Wakaf. 2016.

Djatnika, Rahmat. Wakaf Tanah. Surabaya: Al-Ikhlas. 1982

Edward III, George C. Implementing Public Policy. Washington: Congressional Quarterly Press. 1980.

Hazairin, Demokrasi Pancasila, Jakarta: Bina Aksara, 1983.

Muhammad Daud Ali, Sistem Ekonomi Zakat dan Wakaf, (Jakarta: UI Press, 1988).

Muzarie, H. Mukhlisin. Hukum Perwakafan dan implikasinya terhadap Kesejahteraan Masyarakat. Kementerian Agama. 2010.

Nadjib, A Tuti \& Ridwal Al-Makassary. Wakaf, Tuhan dan Agenda Kemanusiaan, Jakarta: CSRS UIN. 2006.

Supraptiningsih, Umi.Problematika Implementasi Sertifikasi Tanah Wakaf. Jurnal Nuansa, Vol. 9 No. 1 Januari - Juni 201

Untrisna, Virka. Akibat Yuridis Tanah Yang Tidak Terdaftar. Jakarta: UIN Syarif Hidayatullah, 2007.

Wibawa, S. Evaluasi Kebijakan Publik. Jakarta: PT Raja Grafindo Persada. 1994. 
Wibowo, Umbaran. Praktik Pendaftaran dan Pensertifikasian Tanah Wakaf Berdasarkan PP Nomor 24 Tahun 1997 di Kecamatan Cepu Kabupaten Blora. Skripsi. Semarang: Unnes, 2006.

Widodo, Joko. Analisis Kebijakan Publik: Konsep dan Aplikasi Analisis Proses Kebijakan Publik. Malang : Bayu Media. 2011.

Winarno, Budi. Kebijakan Publik Teori dan Proses. Jakarta: Media Pressindo. 2007.

Sumber Internet

https://www.merdeka.com/peristiwa/sengketa-masjid-wakaf-dengan-ahli-warismarak-terjadi-di-karawang.html, diakses 2 April 2017.

http://www.radar-karawang.com/2014/02/persoalan-tanah-wakaf-pesantren.html, diakses 2 April 2017.

https://www.merdeka.com/peristiwa/sengketa-masjid-wakaf-dengan-ahli-warismarak-terjadi-di-karawang.html, diakses 2 April 2017.

Dokumen Peraturan

Direktorat Jendral Bimas Islam. Peraturan Perundangan Perwakafan. Jakarta: Depag, 2006.

Kementerian Agama Data Kementerian Agama Kabupaten Karawang Tahun 2017.

Peraturan Pemerintah Nomor 28 Tahun 1977 tentang Perwakafan Tanah Milik.

Peraturan Pemerintah Nomor 42 Tahun 2006 tentang Pelaksanaan UU No 41 Tahun 2004 tentang Wakaf.

Undang-Undang Republik Indonesia Nomor 41 Tahun 2004 tentang Wakaf.

Undang-Undang Republik Indonesia Nomor 5 Tahun 1960 tentang Peraturan Dasar Pokok-Pokok Agraria.

Undang-Undang Republik Indonesia Nomor 5 Tahun 1960 tentang Pokok Agraria. 